Aubakirova et al. (2021). Consideration of the basic competencies of a preschool teacher in curriculum modernization, International Journal of Cognitive Research in Science, Engineering and Education (IJCRSEE), 9(1), 91-103.

Original scientific paper

UDK:

37.091.3:004

Received: December, 10.2020.

373.2:004

Revised: January, 21.2021.

371.382-053.4:004

Accepted: March, 02.2021.

doi: $10.23947 / 2334-8496-2021-9-1-91-103$

\title{
Consideration of the Basic Competencies of a Preschool Teacher in Curriculum Modernization
}

\author{
Rakhila Zh. Aubakirova1 ${ }^{1 *}$, Gulbanu A. Kabzhanova', Oxana G. Belenko², Nelli Yu. Pigovayeva1 , Alyona A. Kostyunina ${ }^{3}$
}

'Pavlodar State University named after S. Toraighyrov, Pavlodar, Republic of Kazakhstan, e-mail: rakhilaaubakirova@gmail. com; gulbanukabzhan@mail.ru; meganelly84@gmail.com

${ }^{2}$ Shakarim State University of Semey, Semey, Republic of Kazakhstan, e-mail: Oksanapp2004@mail.ru

${ }^{3}$ Gorno-Altai State University, Gorno-Altaisk, Russian Federation, e-mail: kostanatolevna@mail.ru

\begin{abstract}
The work deals with an important aspect of teacher training - the formation of competence in the field of technologization of the pedagogical process. An updated theoretical model of a holistic pedagogical process is presented, which is the basis for coverage of the criteria for the formation of abilities for the constructive and systematic introduction of technologies into pre-school education. The author's questionnaire The Scale of Self-Assessment of Pedagogical Abilities for the Technologization of the Pedagogical Process was presented. The article provides the results of its testing on a sample of a total of 412 respondents, including 170 preschool teachers with work experience from 1 to 25 years, 200 - students-future teachers, 42 - PEF coordinators. Based on the comparison of samples of teachers with different work experience, it describes how the nature of professional activity determines the specific structure of competences in the field of TPP. The experiment was a part of research; authors showed the conditions for the implementation of a special curriculum, which helps effectively prepare teachers for the use of modern educational technologies.

Keywords: pedagogical technologies, professional competences of the teacher, methodological competence, preschool education.
\end{abstract}

\section{Introduction}

The active development of alternative forms and models of education has led to stricter requirements for its quality. The technological approach assumes a focus on clear measurable goals of the pedagogical process, which are recorded in educational standards and programs (in our case the reference point is the competence model of the teacher of a preschool educational institution). It is in accordance with the model of competencies the optimal algorithm of pedagogical actions is selected: techniques, methods, forms and means of monitoring outcomes. The main advantages of the technologization of the pedagogical process (hereinafter referred to as the TPP) are that this approach guarantees the quick achievement of the intended tasks, regardless of who is the object and subject of the pedagogical influence and under what conditions it occurs. The extraordinary diversity of existing technologies allows us to creatively model the pedagogical process, flexibly adapting it to the capabilities of an educational institution and the needs of learners. In addition, the technological approach is a necessary condition for the effective and safe implementation of innovations in teaching practice. It is thanks to the clear algorithmization of actions and the gradual monitoring of the achievement of results that teachers can implement innovative practices, bearing in mind the responsibility towards children and their families. Thus, the quality of modern education largely depends on the ability of qualified teachers to technologize the pedagogical process.

The pedagogical skill is determined by how much teacher is able to find an effective technological solution for the optimal development of personal qualities and life skills of a learner. Accordingly, the formation of teachers' abilities to effectively use technology in training and education is an important part of vocational training. The fundamentals of this work are laid in the theory of the holistic pedagogical process (Khmel, 2008; Slastenin, 2005), competence-oriented approach (Enygin et al., 2018; Khutorskoy, 2017; Seryakova, 2016), a system analysis of pedagogical communication (Zarudnaya et al., 2018). The reform of higher pedagogical education in the Republic of

"Corresponding author: rakhilaaubakirova@gmail.com

(c) (i) 2021 by the authors. This article is an open access article distributed under the terms and conditions of the Creative Commons Attribution (CC BY) license (https://creativecommons.org/licenses/by/4.0/). 
Kazakhstan is accompanied by the work of many scientists: the structure of professionally significant qualities of a teacher is determined (Uspanov, Zhansugirova and Bissenbayeva, 2013); summarised the long-term experience of technologization of the educational process of universities (Kovzhasarova, Nurakhmetov and Aulbekova, 2005); the conceptual framework for the modernization of teacher education has been formulated (Praliev et al., 2015).

The reform of the education system faces the task of preparing a "new time teacher" who is able to train and educate a "new time person". Comprehensive lists of competencies recognised as necessary in educational systems in different countries are offered by Baumert and Kunter (2013), Blömeke (2017), Thrupp (2006). In addition to subject qualifications, the teacher is expected to be motivated, active in social communications, creative and able to act in uncertain situations. Modern researchers (Pankova, Luzan and Sergeeva, 2016; Sánchez-García et al., 2013) indicate a willingness to innovate and a high level of knowledge of information and communication technologies as a universal attribute of teacher qualifications.

Basic training requirements are presented in a number of academic standards: knowledge of various scientific approaches and methodologies in the field of professional specialization; the ability to use a wide range of techniques, to adapt them for creative problem solving; critically assess the short-term and long-term consequences of their actions (Bologna Working Group, 2005); the presence of an integrative understanding as a basis for the original development or application of ideas (Ministry of Education and Science of the Republic of Kazakhstan, 2018). The concept of higher pedagogical education of the Republic of Kazakhstan (Ministry of Education and Science of the Republic of Kazakhstan, 2005) identifies three groups of competences that a new formation teacher should possess: general cultural, subjectoriented and methodological (psychological-pedagogical). The concept methodological competence of the teacher seems extremely important and requires clarification. Mâţă et al, (2010) offer an operational model consisting of five components: ensuring the functionality of the educational process, the use of various teaching methods and tools in a formal and informal context, the exploitation of educational innovations, the management of learning outcomes, the design of teaching activities.

The professional competencies of teachers are not limited to the knowledge of current educational methods and programs. It is extremely important the ability to reasonably select and flexibly adapt existing technologies to the changing demands of the society. We called this complex of knowledge and skills "the ability to technologize the pedagogical process" and consider it as one of the main professional competencies of a teacher. The generally accepted understanding the concept of competence implies the ability to use acquired knowledge and skills in a wide range of standard and non-standard pedagogical situations (Mulder, 2014). Accordingly, competence in the field of TPP presupposes the ability of the teacher to independently apply various elements of pedagogical technologies under certain conditions of interaction for realizing the specific goal of training and education. Recent large-scale studies have shown a close relationship between the level of development of competencies in the field of TPP and the professional and personal growth of teachers, as well as satisfaction with the profession (Kuanysheva et al., 2019).

In spite of the developed theoretical and methodological basis, the TPP does not pay enough attention to the professional training of teachers in the preschool education system. Technologies are most often learned at the level of knowledge, and not at the level of competence. As a result, the teacher today is still perceived in society as a transmitter of information, and not as an active creator of purposeful pedagogical interaction. In addition, the pedagogical process is in constant development, being modernised in view of the accumulated experience. Accordingly, objective transformations are taking place in the system of professional qualities and competencies, which requires more careful study. In view of the events of 2020, which forced educational systems at all levels to switch to distance learning, this problem is becoming even more acute.

Listed above objective problems and contradictions make relevant the purpose of this publication - to determine the individual abilities of teachers in the technologization of the pedagogical process in the conditions of preschool preparation. The research is aimed at solving the following topical issues: 1) What is the real level of competence of preschool teachers in the field of TPP? 2) How does the structure of competencies depend on the specifics of professional activity? 3) What are the most effective ways to acquire and improve the competence of teachers in the field of TPP?

Practical work is based on the author's theoretical model, which has been introduced into the preschool education system of the Republic of Kazakhstan more than ten years ago. The results of many years of practice have proved its effectiveness and allowed presenting it in a more current modification (Aubakirova, 2011a; 2011b). 


\section{Author's model of the technologization of pedagogical process}

We consider the holistic pedagogical process as a systemic category, the constituent elements of which are the following: conditions of education; relationships in the system "teacher-learner"; common goals and particular learning objectives; the content of training, which is implemented in specific means of pedagogical interaction; organization and management of the educational process; ways of consistent monitoring of performance.

The structural elements of the pedagogical process are closely interrelated and together represent a dynamic cycle (Figure 1).

The pedagogical process begins with the organization of a harmonious personality-oriented interaction in the system "Teachers - Pupils" (as well as "Teachers-Parents", "Pupils - Pupils"). Purposeful regulation requires timely diagnostics, analysis of these relationships as a part of a holistic pedagogical process. Next, the teacher formulates the urgent tasks of interaction and expediently models the pedagogical process. The main pedagogical goals and the content of education are determined by external factors: the needs of society are worked out by the pedagogical community and are embodied in curricula and educational standards. Acting within this framework (as well as using the resources of a particular educational institution), the teacher is free in the means of realization - in what way the direct pedagogical interaction will be realised. At this stage his professional skills and pedagogical culture are realised to the greatest extent. Systemic management of the pedagogical process implies constant, phased control and timely correction of the used technology. The pedagogical cycle ends with an analysis of the results: in the context of the tasks set for the development of learners, the effectiveness of using a particular technology in these conditions, their own professional actions and their consequences. This allows you to simulate a new pedagogical task at a new level of relationships.

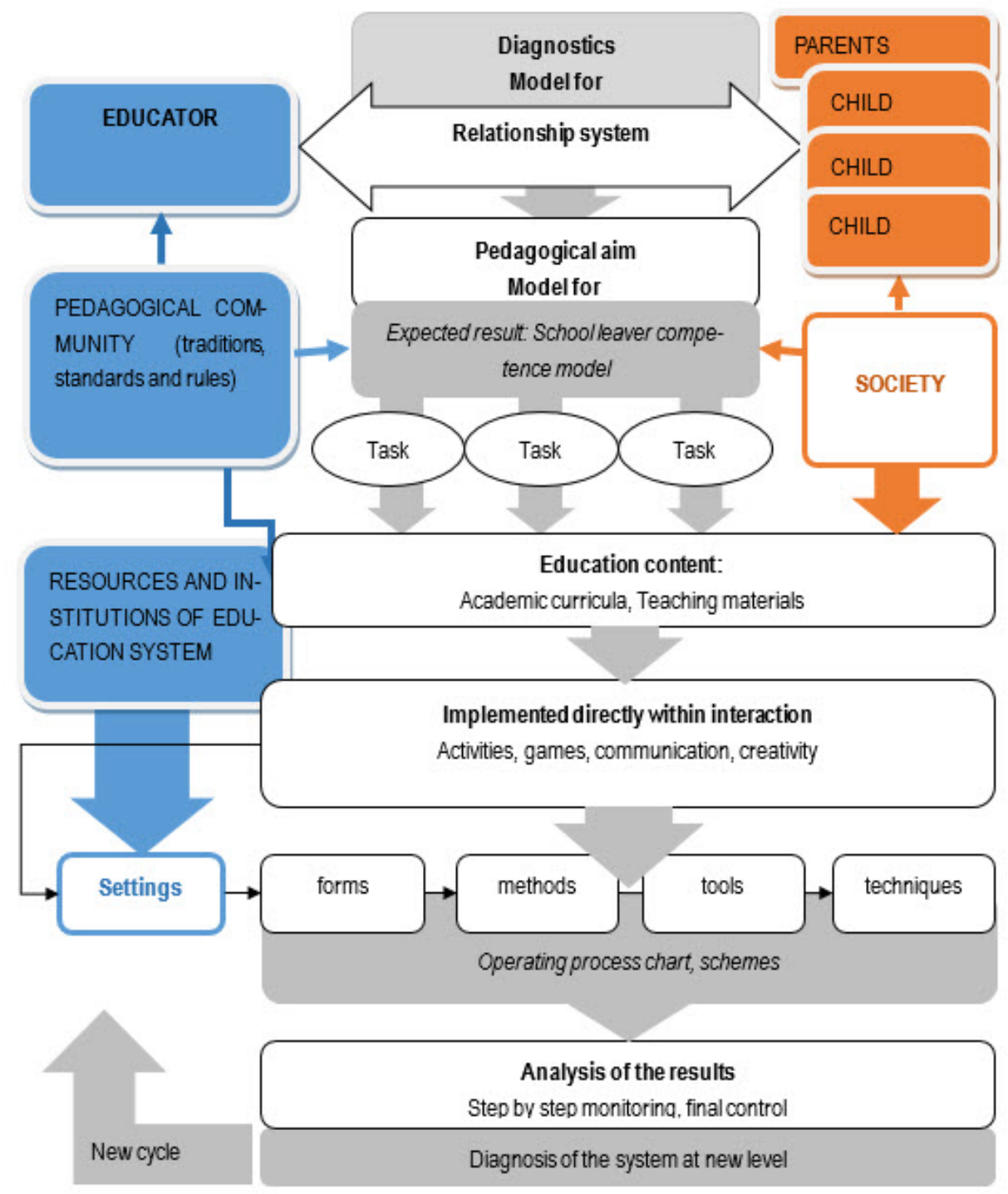

Figure 1. Structural components of the pedagogical process 
Based on the presented model, we formulated the structural criteria for the formation of pedagogical competence in the field of TPP: components:

(1) Establishment of pedagogically expedient relations. This criterion includes the following interaction.

A) The ability to timely and accurately diagnose relationships in the system of pedagogical

B) Knowledge of techniques and the ability to regulate the interaction in the educational mechanisms of the ECE pedagogical process.

C) Purposeful self-improvement of the teacher based on the reflection of their own professional growth and personal qualities.

(2) Modelling the pedagogical process:

A) Awareness of the unity of the various goals and objectives of educational activities.

B) Forecasting and design of the pedagogical process in accordance with the tasks of the development of preschoolers.

C) Planning of educational activities in the framework of the approved curriculum and the specific conditions for their implementation in an educational institution.

(3) The implementation of the pedagogical process:

A) The implementation of the content of education in the context of the objectives and current tasks.

B) Knowledge of effective means, forms, methods and techniques, the ability to apply them in direct work with preschoolers. interaction.

C) Creative design of the pedagogical process when changing conditions and situations of

(4) The organization and management of the pedagogical process is associated with the constant monitoring of the flow of the pedagogical process, the ability to take into account the factors that impede or stimulate its implementation:

A) Phased monitoring of the implementation of the pedagogical process at each stage and in each element, the ability to make adjustments.

B) Tracking of pedagogical innovations.

(5) The analysis of the implemented technology occurs systematically throughout the whole pedagogical cycle and includes:

A) Analysis of the initial data and conditions of a specific pedagogical situation.

B) Understanding the pedagogical goal and tasks at each stage and in each element of the pedagogical process.

C) Further transformation of technology, taking into account the corrections made to improve the holistic educational process.

\section{Materials and Methods}

The main method of obtaining information on the formation of pedagogical competence in the field of TPP is self-analysis of pedagogical activity, which implies a well-developed reflection and ability for self-observation of the teacher. We have developed a self-reporting methodology based on the criteria set forth above. The scale is a screening tool that provides data on the level of development of pedagogical competence (as a construct of knowledge, skills and attitudes) in the field of TPP. This allows evaluating the effectiveness of educational and training programs aimed at developing the appropriate qualities of teachers.

To measure the level of development of each component, we employed a 5-point scale, where its extreme poles indicated the lack of competence ( 0 points), and its maximum severity (4 points):

0 - the ability is not expressed;

1 - the ability manifests itself sporadically, quite rarely;

2 - the ability to manifest itself occasionally, from case to case;

3 - the ability to manifest itself frequently, in most cases.

4 - the ability to manifest itself consistently, almost always.

To obtain the total score we summed the scores for all 13 items. In addition to calculating the total score, the analysis of answers to individual questions and blocks of the scale allows to draw conclusions about the structural components (abilities) in the implementation of educational technologies. Thus, we have the opportunity to create an individual profile of the abilities of a specialist to identify the leading components and potential possibilities that need to be improved. 
Processing and interpretation of the estimates obtained was based on a direct interpretation of the average score, based on the values of the proposed 5-point Likert scale. We consider 1.5-2.5 points as an average level of competence - ability sometimes manifests itself, from case to case. In this case, we can talk not about a stable explicit tendency (towards the manifestation of competence or its absence), but about the fact that the ability is realized in certain pedagogical situations that contribute to its manifestation. The excess of this factor indicates the intensity of abilities and skills, a decrease indicates the insufficient formation of competences in the field of TPP.

The sample was formed from "natural" socio-professional groups - teachers with different specializations, work experience and level of professional skills:

(1) bachelors majoring at Preschool Education of the Semipalatinsk State Pedagogical Institute and the Shakarim State University in Semey (162 people);

(2) masters majoring at Pedagogy and Methods of Elementary Education of the Semipalatinsk State Pedagogical Institute, 38 people,

(3) 170 preschool teachers in Semey, who undergo refresher courses (we divided the sample into two subgroups: with work experience up to 10 years and from 11 to 25 years);

(4) methodologists of preschool educational institutions, PEF coordinators - participants of seminars of international project TEMPUS EDUCA JEP 517504 at Shakarim State University (42 people)

Participation in the study was voluntary. All respondents gave their consent to the processing and use of personal data.

According to the results of diagnostics, we calculated descriptive statistics. An assessment of the individual points of the scale in different samples was also carried out - thus conclusions were made about the structure and dynamics of the formation of individual components of teachers' competence in the field of TPP.

Considering that a teacher should be an expert in a wide range of methodological areas and be ready for introduction of innovative educational technologies, we have developed a special training course "Modern educational technologies in the system of a teacher's professional activities" (in collaboration with A. Magauov and Sh. Duisembekov). The objectives of the course: to reveal the essence of educational technologies; to form the ability of teachers to use them in practice; to promote the development of a creative and constructive approach to teaching. The material of the special course is organised in three modules: Education technology conceptual basis, Personalities of a teacher and learners in the education technologies system, Didactic design of education technologies. The volume of material includes 14 hours of lectures, 10 hours of seminars, 6 hours of practical training.

The program has been tested on a selection of undergraduates in the specialty Pedagogics and Primary Education Methodology at the Semipalatinsk State Pedagogical Institute (two groups with a total of 38 people). A teaching experiment was organised as follows: in the experimental group, the course was introduced during the first semester of the school year, in the control group it was transferred to the schedule of classes in the second semester. Thus, we were able to record the results of the implementation of the curriculum and analyse its impact on the formation of competences in the field of TPP.

For starting and final measurements the self-assessment scale of pedagogical skills for the TPP presented above was used. Sample rates were calculated for different professional groups, the reliability of measurements was verified. Inferential statistics were used in addition to descriptive statistics. Statistical analysis was performed using the nonparametric tests that allow comparing small groups and ignoring deviations from the normal distribution: Wilcoxon T-test for measuring the shift in values as a result of training, and Mann-Whitney U-test for comparing control and experimental groups. 


\section{Results}

1. Identification of the formation of the ability to technologise the pedagogical process among teachers of the preschool education system

First of all, we have calculated the total score of the self-assessment scale of abilities for the TPP. These data are the basis for the development of group test standards in evaluation of the studied abilities in different selections - Table 1.

Table 1

Data descriptive statistics of the total score of the scale of self-assessment of the abilities of the TPP the selections of teachers with different experience

\begin{tabular}{lllcccc}
\hline No & \multicolumn{1}{c}{ Selection of teachers: } & N & $\begin{array}{c}\text { data interval } \\
\text { (min-max) }\end{array}$ & M & SD & SE \\
\hline 1 & bachelors - prospective teachers & 162 & $7-24$ & 14,55 & 3,44 & 0,27 \\
2 & masters - prospective teachers & 38 & $8-25$ & 16,86 & 4,16 & 0,67 \\
& $\begin{array}{l}\text { teachers/educators of PEF (preschool educational } \\
\quad \text { institutions): }\end{array}$ & 170 & $11-34$ & 22.65 & 4.28 & 0.32 \\
3 & - track record 1-10 years & 72 & $10-28$ & 19.66 & 3.30 & 0.38 \\
4 & - track record 11-25 years & 98 & $13-34$ & 25.65 & 4.27 & 0.43 \\
5 & PEF coordinators & 42 & $17-29$ & 23.71 & 2.55 & 0.43 \\
\hline
\end{tabular}

Selected rarely give themselves a score above 2 points. This indicates a lack of capacity development in the field of TPP. We see that teachers and practitioners with experience of more than 10 years are most confident in their competence in application of educational technologies. Approximately the same average results show selected teachers with experience of 1-10 years and methodologists of preschool institutions. At the same time, in the selection of methodologists, the smallest data scattering is that none of the respondents showed a low level of parameter expression. It is expected that the lowest indicators of the formation of pedagogical abilities in TPP were found among students - future teachers (bachelors have lower rates more often than masters).

The calculated Cronbach's Alpha was 0.895 , which indicates a high internal consistency of the scale.

The distribution of estimates for individual points of the scale in different selected people is in some way interesting. Table 2 presents the average arithmetic for questions. 
Table 2

Average estimates of individual criteria for pedagogical abilities for the technologization of the pedagogical process in different selected persons

\begin{tabular}{|c|c|c|c|c|c|c|c|}
\hline \multirow[t]{2}{*}{ No } & \multirow{2}{*}{$\begin{array}{l}\text { Criteria of evaluating pedagogical competence in the field of } \\
\text { TPP }\end{array}$} & \multicolumn{5}{|c|}{$\begin{array}{c}\text { Average marks of selected } \\
\text { teachers }{ }^{*}\end{array}$} & \multirow{2}{*}{$\begin{array}{c}\begin{array}{c}\text { Lsd. } \\
(\mathrm{N}=412) \\
\text { all }\end{array}\end{array}$} \\
\hline & & 1 & 2 & 3 & 4 & 5 & \\
\hline 1 & $\begin{array}{l}\text { Able to timely and accurately diagnosing relations in "educator } \\
\text { - learners" system }\end{array}$ & 0.8 & 0.9 & 1.4 & 1.8 & 1.8 & 1.37 \\
\hline 2 & $\begin{array}{l}\text { Able to adjust the interrelating mechanisms of the education pro- } \\
\text { cess }\end{array}$ & 0.9 & 1.1 & 1.8 & 2.2 & 2.1 & 1.48 \\
\hline 3 & $\begin{array}{l}\text { Make constant efforts for self-improvement both personal and } \\
\text { professional one }\end{array}$ & 1.7 & 1.9 & 1.5 & 1.9 & 1.8 & 1.83 \\
\hline 4 & $\begin{array}{l}\text { Aware of the common purpose of the education process, able to } \\
\text { single out concrete tasks for implementation }\end{array}$ & 1.6 & 1.9 & 1.6 & 2 & 2.2 & 2.01 \\
\hline 5 & $\begin{array}{l}\text { Able to project pedagogical interrelation and able to forecast the } \\
\text { results of application of technologies }\end{array}$ & 2.2 & 2.2 & 2 & 2.2 & 2.4 & 2.35 \\
\hline 6 & $\begin{array}{l}\text { Now how to reach the needed results in specific conditions of } \\
\text { activity }\end{array}$ & 1.5 & 1.5 & 1.8 & 2.2 & 2.6 & 1.99 \\
\hline 7 & $\begin{array}{l}\text { Select and apply affective means and technic of the pedagogical } \\
\text { interrelations }\end{array}$ & 1.2 & 1.7 & 2.1 & 2.8 & 2.2 & 2.04 \\
\hline 8 & $\begin{array}{l}\text { Adjust and make up creatively the teaching process, in course } \\
\text { of change of the educating situation conditions }\end{array}$ & 0.9 & 1.1 & 1.8 & 3.1 & 1.9 & 1.60 \\
\hline 9 & $\begin{array}{l}\text { Control the education process at each stage and each element } \\
\text { makes corrections }\end{array}$ & 1.3 & 1.4 & 1.6 & 1.8 & 1.5 & 1.41 \\
\hline 10 & $\begin{array}{l}\text { Master the ways to organise pedagogical activities in scientific } \\
\text { manner }\end{array}$ & 0.5 & 0.6 & 0.7 & 1 & 1.1 & 0.95 \\
\hline 11 & $\begin{array}{l}\text { Analyse the inputs and conditions of a specific pedagogical sit- } \\
\text { uation }\end{array}$ & 1 & 1.2 & 0.8 & 1.1 & 1.2 & 0.97 \\
\hline 12 & $\begin{array}{l}\text { Able to think over each aim and task at every stage of education } \\
\text { process }\end{array}$ & 0.7 & 0.8 & 1.1 & 1.3 & 1.6 & 1.16 \\
\hline 13 & $\begin{array}{l}\text { Able to transform and to adjust the technologies in order to im- } \\
\text { prove the comprehensive educating process }\end{array}$ & 0.2 & 0.5 & 1.5 & 2.2 & 1.4 & 1.08 \\
\hline
\end{tabular}

*The numbering of the selected people is as follows: 1 - bachelors; 2 - masters, 3 - teachers with experience of 1-10 years;

4 - teachers with experience of $11-25$ years; 5 - preschool methodologists.

Based on the data obtained, the most problematic components of the TPP among teachers are proficiency in the methods of scientific organization of pedagogical work (paragraph 10, Lsd=0.95), analysis of the initial data of a particular pedagogical situation (p.11, Lsd=0.97) and transform technologies to improve the holistic pedagogical process (p.13, $\mathrm{Lsd}=1.08$ ). The respondents use these competencies and abilities extremely rarely, or do not use them at all. The construction of expedient activities requires more close attention, that is, an understanding of the pedagogical goals and objectives in each element of the educational process (p.12, Lsd=1.16).

In general, the results show a lack of ability to system analysis of the entire pedagogical cycle in the general structure of pedagogical competence in the field of TPP.

When analysing the estimates of points, the specificity of different selected people is clearly visible:

- Bachelors have lower marks on most points of the scale compared to masters. In general, the future teachers are characterised by insufficient formation of the ability to establish pedagogically expedient relations with pupils. Interestingly, they overestimate their abilities to analyse the initial data of the pedagogical situation, to design the pedagogical process and to predict the result (p.5 and p.11 of the 
scale is the average assessment at the level of teachers with work experience of over 10 years).

- Young teachers with experience from 1 to 10 years are less than the rest make efforts for continuous personal and professional improvement (p.3, Lsd=1.5). In this group, the lowest estimate of the ability to design the pedagogical process according to the set goal and predict its results was obtained (p.5, Lsd=2.0). Estimates of the remaining pedagogical abilities are significantly increased compared with the students, but less pronounced than in the group of experienced teachers.

- Experienced teachers with work experience 11-25 years demonstrate the highest ability to regulate the interaction between the participants of the holistic pedagogical process ( $p .2$, Lsd=2.2); to the effective selection and application of training and education facilities (p.7, Lsd=2.8); to the transformation of the technologies used (p.13, Lsd=2.2). A distinctive feature of the selection is a flexible, adaptive and creative design of the pedagogical process taking into account the real conditions of the pedagogical situation. It is this ability that they note as the most frequently used in the work (p. 8, Lsd=3.1).

- Methodologists of preschool institutions have a characteristic structure of abilities, in which the component of the modeling the pedagogical process prevails. They realize the goals and objectives of the pedagogical process better than all the other categories of specialists, and accordingly design it (p.4, Lsd=2.2); know what means to effectively implement the content of education (p.6, Lsd=2.6); able to predict the results of the application of technology in specific conditions of activity (p.5, Lsd=2.4). The whole range of pedagogical competencies in the field of TPP is developed at a fairly high level. Slightly lagging behind is the possession of the methods of the scientific organization of pedagogical work (p.10, Lsd=1.1).

The data obtained clearly demonstrate how the specificity of professional activity influences the development of individual components of the competence of teachers in the field of TPP. In addition, we found out the role of vocational training in the formation of these abilities.

2. Formation of abilities and competencies of teachers based on the concept of technologization of the pedagogical process

Formative influence occurred in the selection of masters, who during the 30 academic hours mastered the special course "Modern educational technologies in the system of professional activity of a teacher." The diagnostic results in the control and experimental group are presented in Table 3.

Table 3

Statistical significance of differences in the level of ability to technologize the pedagogical process in the experimental and control groups

\begin{tabular}{lrrrccc}
\hline \multicolumn{1}{c}{$\mathrm{N}$} & $\mathrm{M}$ & $\mathrm{SD}$ & Sum of Ranks & U Mann-Whitney & Asymp.Sig. (2-tailed) \\
\hline Primary diagnosing & & & & & & \\
Control group & 19 & 14.89 & 3.71 & 361.5 & 171.5 & 0.790 \\
Experimental group & 19 & 14.94 & 4.07 & 379.5 & & \\
Secondary diagnosing (after the training) & & & & \\
Control group & 19 & 15.05 & 3.64 & 288 & 98 & 0.014 \\
Experimental group & 19 & 17,58 & 4,44 & 453 & & \\
\hline
\end{tabular}

The level of the studied phenomenon in the experimental and control groups during the initial diagnosis was the same. In the control group, we observe a slight increase in the indicator due to the natural development of professionalism of future teachers in the process of training in the magistracy. At the same time, the level of development of competencies in the experimental group significantly increased after passing the training course. As a result, the groups began to differ significantly in the value of the parameter $(p=0.014)$. After the experiment, the general level of abilities to the TPP in the experimental group exceeds the level in the control group.

Following the principle of phased control of the results of the use of educational technology, we carried out diagnostic measurements at each stage of the formative experiment. This allowed us to trace the dynamics of changes in abilities to the TPP (Figure 2). 


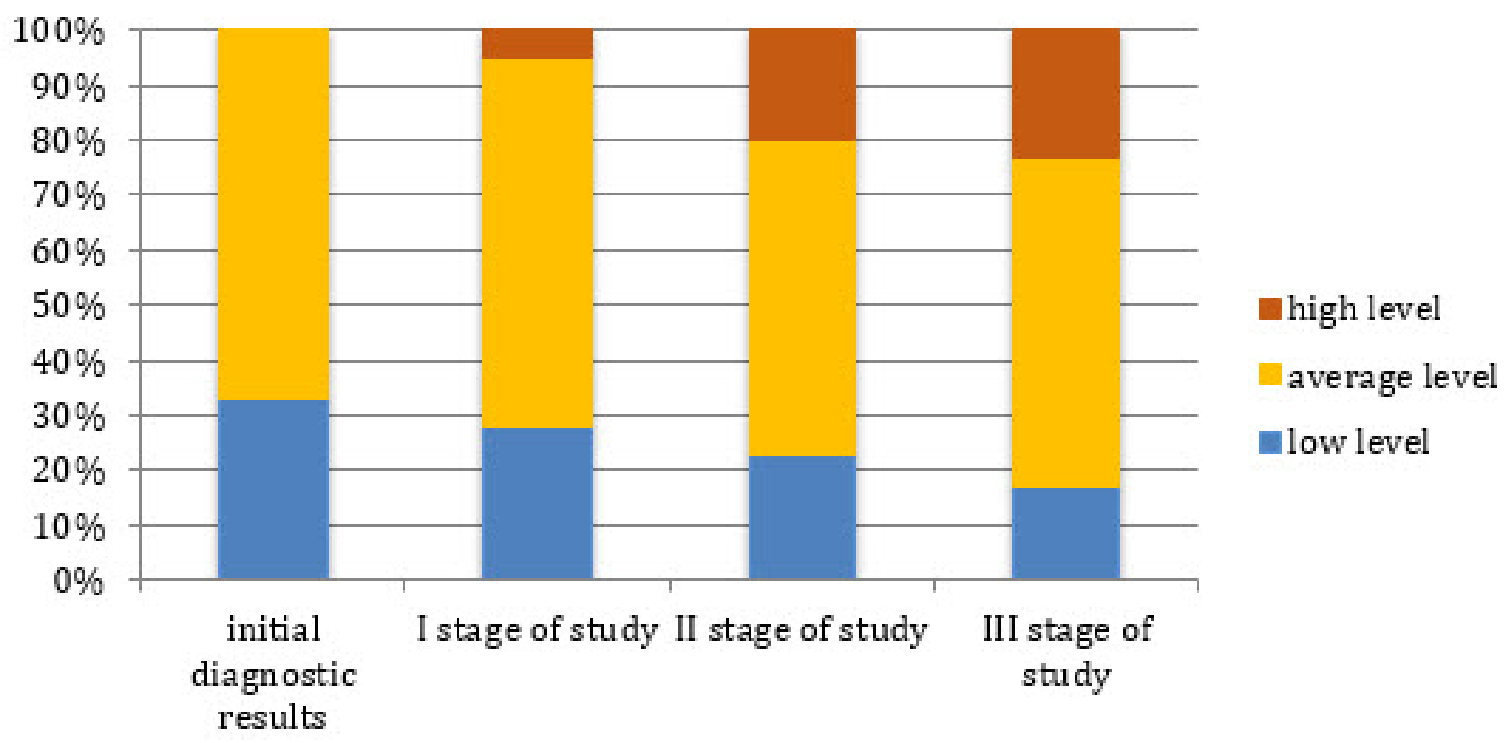

Figure 2. State of competency of the investigated phenomenon in experimental group ( $N=19$, in \%)

As a result of the training course in the experimental group, the number of teachers with high selfesteem in the field of TPP gradually grew. At the end of the experiment, it reached $23 \%$. It is important that the greatest increase occurs at the second stage of training, when practical exercises begin using active technologies. At the same time, the number of teachers with a low level of competence decreased from 33 to $17 \%$.

Thus, as a result of mastering the special course "Modern educational technologies in the system of a teacher's professional activity", future teachers have the pronounced positive dynamics in the formation of competences in the field of TPP.

\section{Discussions}

Approbation of the questionnaire "The scale of self-assessment of pedagogical abilities for the technologization of the pedagogical process" showed high internal consistency of items, which indicates the reliability of the measurement. The common basis for the set of questions also indirectly confirms the proposed theoretical model of the TPP criteria. Analysis of means confirmed assumption that the professional competencies of preschool teachers are insufficiently developed.

An important result concerns the relatively low indices of abilities to the TPP among young teachers compared with university graduates. This fact can be explained with the help of the Daning-Kruger rule on metacognitive distortion, as a result of which specialists with low qualifications make erroneous conclusions about their own capabilities to design and regulate pedagogical interaction. Facing real professional situations, young teachers are aware of their own limits and mistakes, as a result of which the self-assessment of competencies decreases. In the group of experienced teachers, the high grades reflect an objective growth of professional skills.

The data of Hoy and Spero (2005) confirm the increase in self-efficacy during the training of future teachers. Therefore, when introducing professional development programs, one should pay attention to the adequacy of teachers' self-assessment and develop their ability to self-knowledge. Undoubtedly, knowledge of their potential internal resources, abilities and limitations determines the increase in responsibility and the desire of teachers to actively participate in their own development. Thus, the nature of the professional activities of teachers determines the structure of competences in the field of TPP. The ability to constructively use pedagogical technologies can be purposefully developed, which is confirmed by the results of a teaching experiment. Among modern ways to improve the pedagogical process, the theory and methodology of pedagogical innovation should be noted (Hannan, 2005; Walder, 2014), the introduction of public distance learning, e-learning (Bidin and Ziden, 2013; Fominykh et al., 2016); defining the teacher's ethical profile (Jeder, 2013).

A characteristic feature of the dynamics of the formation of skills in the process of mastering the special course is the practical orientation of the activity. Opinion about the importance of the workshop in 
teacher training has been repeatedly expressed in pedagogical science and found numerous empirical evidences. It is necessary to recognise that the process of teaching practice needs more thorough structuring and technologization. In the preparation of teachers, it is necessary to focus on the ability to design the pedagogical process in accordance with actual tasks. In addition to clear target orientations of vocational education, it is important to use precisely those methodical techniques and practices that teachers will later implement in the training of children. We believe that this is the most optimal and effective way to show how the technology works, to reveal its advantages and limitations, to finally form methodological competence of teachers.

\section{Conclusions}

Surveyed Kazakhstan's preschool teachers are not confident enough in their abilities and competencies in the field of technologization of the pedagogical process. The indicators of self-assessment of pedagogical abilities for the technologization of the pedagogical process increase with increase of the level of education and professional experience.

The structure of abilities differs significantly among teachers with different work experience. The position of methodologists implies assistance to teaching staff in the specification of the content, methods and means of training. They often develop information and teaching materials and rarely communicate directly with children and parents. This imposes a specific imprint on the structure of competences in the field of TPP (the predominance of the components of the educational process modelling). Methodologists significantly lag behind practicing educators in their ability to adaptively design the pedagogical process, to select effective methods and techniques in a real situation of interaction. That is, the transformation of technology, their creative application occurs in practice, with the accumulation of experience working with various techniques. This is important to consider in order understanding the nature of innovation.

To reach an adequate level of these qualities, it is necessary to provide special training, which necessarily provides for the use of active teaching methods (acquiring relevant attitudes, knowledge, and approbation of skills). Particular attention in this issue should be paid to a system analysis of a holistic pedagogical cycle, an understanding of pedagogical goals in each element of the educational process, as well as the ability to transform existing technologies to achieve the set objectives. The competences further improve directly in the professional activity, in solving real pedagogical problems, and conscious self-development.

\section{Limitations}

Although the problems described are of a global nature, the empirical results obtained refer to the surveyed Kazakhstan's preschool teachers and students. We expect a change in trends in the process of gradual reform of the system of professional training of teachers. 


\section{Appendix A}

Scale of self-assessment of pedagogical abilities for the technologization of the pedagogical process (stimulus material)

Instructions: You are offered a number of questions that relate to the ability to practical implementation of various educational technologies in the educational process. Remember your individual experience and evaluate how often this or that ability manifests itself in your work.

\begin{tabular}{|c|c|c|c|c|c|c|}
\hline № & Self-Reporting Points & \multicolumn{5}{|c|}{ Rating Scale } \\
\hline 1 & $\begin{array}{l}\text { I am able to diagnose in time and accurately the relationship in the system } \\
\text { "teacher-pupils" }\end{array}$ & 0 & 1 & 2 & 3 & 4 \\
\hline 2 & $\begin{array}{l}\text { I am able to regulate interactions in the educational mechanisms of the pedagogical } \\
\text { process }\end{array}$ & 0 & 1 & 2 & 3 & 4 \\
\hline 3 & I make a focused effort to continually self-improve, both personally and professionally & 0 & 1 & 2 & 3 & 4 \\
\hline 4 & $\begin{array}{l}\text { I realize the general goal of the pedagogical process, I can identify specific tasks for its } \\
\text { achievement }\end{array}$ & 0 & 1 & 2 & 3 & 4 \\
\hline 5 & $\begin{array}{l}\text { I am able to design pedagogical interaction according to the set goal, I predict the result } \\
\text { of using particular technology }\end{array}$ & 0 & 1 & 2 & 3 & 4 \\
\hline 6 & I know how to implement the content of education in specific conditions of activity & 0 & 1 & 2 & 3 & 4 \\
\hline 7 & $\begin{array}{l}\text { I select and apply effective means, forms, methods and techniques of pedagogical } \\
\text { interaction }\end{array}$ & 0 & 1 & 2 & 3 & 4 \\
\hline 8 & $\begin{array}{l}\text { I creatively adapt, construct the educational and educational process when the initial } \\
\text { conditions of the pedagogical situation change }\end{array}$ & 0 & 1 & 2 & 3 & 4 \\
\hline 9 & $\begin{array}{l}\text { I exercise control of the pedagogical process at each stage and in each element, mak- } \\
\text { ing adjustments }\end{array}$ & 0 & 1 & 2 & 3 & 4 \\
\hline 10 & I possess the methods of scientific organization of my pedagogical work & 0 & 1 & 2 & 3 & 4 \\
\hline 11 & I analyse the initial data and conditions of a specific pedagogical situation. & 0 & 1 & 2 & 3 & 4 \\
\hline 12 & $\begin{array}{l}\text { I interpret the pedagogical goal and tasks at each stage and in each element of the } \\
\text { pedagogical process }\end{array}$ & 0 & 1 & 2 & 3 & 4 \\
\hline 13 & $\begin{array}{l}\text { I am able to transform and adapt technologies in order to improve the pedagogical } \\
\text { process }\end{array}$ & 0 & 1 & 2 & 3 & 4 \\
\hline
\end{tabular}

\section{Acknowledgements} experience.

We are grateful to the participants in the study for the information provided about their professional

\section{Conflict of interests}

The authors declare no conflict of interest.

\section{References}

Aubakirova, R. Zh. (2011a). Модель технологизации педагогического процесса в условиях предшкольной подготовки [Model of technologization of the pedagogical process in the context of preschool training]. Вестник СГПИ, 1(21), 19-26.

Aubakirova, R. Zh. (2011b). Результаты опытно-экспериментальной работы по технологизации педагогического процесса в условиях предшкольной подготовки [The results of experimental work on the technologization of the pedagogical process in the context of preschool training]. Мир науки, культуры, образования, 3, 188-190. Retrieved from https://cyberleninka.ru/article/n/rezultaty-opytno-eksperimentalnoy-raboty-po-tehnologizatsii-pedagogicheskogoprotsessa-v-usloviyah-predshkolnoy-podgotovki

Baumert, J., \& Kunter, M. (2013). The COACTIV model of teachers' professional competence. In Cognitive activation in the 
Aubakirova et al. (2021). Consideration of the basic competencies of a preschool teacher in curriculum modernization, International Journal of Cognitive Research in Science, Engineering and Education (IJCRSEE), 9(1), 91-103.

mathematics classroom and professional competence of teachers (pp. 25-48). Springer, Boston, MA. https://doi. org/10.1007/978-1-4614-5149-5_2

Bidin, S., \& Ziden, A. A. (2013). Adoption and application of mobile learning in the education industry. Procedia-social and behavioral sciences, 90, 720-729. https://doi.org/10.1016/j.sbspro.2013.07.145

Blömeke, S. (2017). Modelling teachers' professional competence as a multi-dimensional construct. In S. Guerriero Pedagogical Knowledge and the Changing Nature of the Teaching Profession (pp. 119-135). Paris: OECD Publishing. Retrieved from http://www.iep.edu.gr/images/IEP/EPISTIMONIKI_YPIRESIA/Epist_Grafeia/EU_Policy/2017/2017-05-11_ OECD-Pedagogical-Knowledge.pdf

Bologna Working Group. (2005). A framework for qualifications of the European higher education area. Bologna Working Group Report on Qualifications Frameworks (Copenhagen, Danish Ministry of Science, Technology and Innovation). Retrieved from http://ecahe.eu/w/index.php/Framework_for_Qualifications_of_the_European_Higher_Education_Area

Eferova, A. R. (2018). Methodological Approaches to University Instructors Professional Foreign Languages Competence Development. The Journal of Social Sciences Research, (S5), 375-381. Retrieved from https://www.elibrary.ru/item. asp?id $=37528028$

Enygin, D. V., Fominykh, N. I., Bubenchikova, A. V., Arregi-Orue, J. I., \& Aubakirova, R. (2018). To the definition of the notion, multicultural educational environment". Astra Salvensis, 1(11), 601-616. Retrieved from https://www.ceeol.com/search/ article-detail?id=667201

Fominykh, N., Barsova, O., Zarudnaya, M., \& Kolomiytseva, N. (2016). Approaches to prospective economists professional foreign language training in computer orientated language learning environment. International Journal of Environmental and Science Education, 11(18), 12067-12083. Retrieved from http://www.ijese.net/makale_indir/lJESE_1666_ article_584690a849db0.pdf

Hannan, A. (2005). Innovating in higher education: contexts for change in learning technology. British Journal of Educational Technology, 36(6), 975-985. https://doi.org/10.1111/j.1467-8535.2005.00568.x

Hoy, A. W., \& Spero, R. B. (2005). Changes in teacher efficacy during the early years of teaching: A comparison of four measures. Teaching and teacher education, 21(4), 343-356. http://dx.doi.org/10.1016/j.tate.2005.01.007

Jeder, D. (2013). Teachers' ethic responsibilities in the practice of education and training. Procedia-Social and Behavioral Sciences, 92, 432-436. https://doi.org/10.1016/j.sbspro.2013.08.697

Khakimhan, U., Kuljaisha, Z., \& Zhanat, B. (2013). Professionally important qualities inherent in a teacher-A measure of rationality regarding pedagogical processes. Procedia-Social and Behavioral Sciences, 89, 751-755. https://doi. org/10.1016/j.sbspro.2013.08.927

Khmel, N. D. (2008). Теория и технология реализации целостного педагогического процесса [Theory and technology of the implementation of a holistic pedagogical process]. Алматы: КазНПУ им. Абая.

Khutorskoy, A. V. (2017). Методологические основания применения компетентностного подхода к проектированию образования [Methodological foundations for applying the competence approach to designing education]. Bысuеe образование в России, 12, 85-91. Retrieved from https://cyberleninka.ru/article/n/metodologicheskie-osnovaniyaprimeneniya-kompetentnostnogo-podhod-k-proektirovaniyu-obrazovaniya

Kovzhasarova, M. R., Nurakhmetov, N. N., \& Aulbekova, G. D. (2005). Технологизация учебного процесса: казахстанский опы IT [Technologization of the educational process: Kazakhstan experience]. Алматы: Зият-Пресс.

Kuanysheva, B. T., Aubakirova, R. Z., Pigovayeva, N. I., \& Fominykh, N. I. (2019). Technologization of the Pedagogical Process as a Teacher Self-Improvement Factor. Journal of Social Studies Education Research, 10(3), 404-433. https://files.eric. ed.gov/fulltext/EJ1229395.pdf

Mâţă, L., Dumitriu, C., Dumitriu, G., Timofti, I., \& Stanciu, M. (2010). Operational model for the development of methodological competences at beginning teachers. Lucrări Ştiinţifice. Seria Agronomie, 53(2), 335-338. Retrieved from http://www. uaiasi.ro/revagrois/PDF/2010_2_337.pdf

Minister of Education and Science of the Republic of Kazakhstan. (2018). Об утверждении государственных общеобязательных стандартов образования всех уровней образования [On approval of state educational standards of all levels of education]. Retrieved December 6, 2019, from https://online.zakon.kz/Document/?doc_ id $=33329539 \#$ pos $=0 ; 0$

Ministry of Education and Science of the Republic of Kazakhstan. (2005). Концепция высшего педагогического образования Республики Казахстан [The concept of higher pedagogical education of the Republic of Kazakhstan]. Retrieved December 6, 2019, from https://online.zakon.kz/Document/?doc_id=30020913\#pos=6;-56

Mulder, M. (2014). Conceptions of professional competence. In International handbook of research in professional and practicebased learning (pp. 107-137). Springer, Dordrecht. https://doi.org/10.1007/978-94-017-8902-8_5

Pankova, G. V., Luzan, M. M., \& Sergeeva, M. А. (2016). Развитие профессиональной компетентности педагога ДоО в контексте ФГОС ДО и ПС (Профрстандарта) [The development of professional competence of a teacher of secondary education in the context of the Federal State Educational Standards for Subsidiaries and teaching staff (Profstandard)]. Научно-методический электронный журнал "Концепm", 10, 231-235. Retrieved from http://ekoncept.ru/2016/56854.htm.

Praliev, S., Zhampeisova, K., Khan, N., Kolumbaeva, Sh., \& Kaydarova, A. (2015). Концептуальные основы системной модернизации педагогического образования в Республике Казахстан [Conceptual foundations of the system modernization of pedagogical education of the Republic Kazakhstan]. Педагогика и психология: научнометодический журнал КазНПУ им. Абая, 1(22), 44-60. Retrieved from https://kaznpu.kz/docs/ins_pedagogiki_psih/ Sistemnaya modernizasiya1.pdf

Sánchez-García, A. B., Marcos, J. J. M., GuanLin, H., \& Escribano, J. P. (2013). Teacher development and ICT: The effectiveness of a training program for in-service school teachers. Procedia-Social and Behavioral Sciences, 92, 529-534. https://doi. org/10.1016/j.sbspro.2013.08.713

Seryakova, S. B. (2016). Технологический подход в проектировании образовательных программ [Technological approach to designing of educational programs]. Преподаватель XXI век, 1(2), 24-32. Retrieved from https://cyberleninka.ru/ article/n/tehnologicheskiy-podhodv-proektirovanii-obrazovatelnyh-programm

Slastenin, V. A. (2005). Профессионализм учителя как явление педагогической культуры [Teacher's professionalism as 
a phenomenon of pedagogical culture]. Педагогическое образование и наука, (3), 14-28. Retreived from https:// cyberleninka.ru/article/n/professionalizm-uchitelya-kak-yavlenie-pedagogicheskoy-kultury-1

Thrupp, M. (2006). Professional standards for teachers and teacher education: Avoiding the pitfalls. Wellington: Post Primary Association and New Zealand Educational Institute.

Uspanov, K., Zhansugirova, K., \& Bissenbayeva, Z. (2013). Professionally important qualities inherent in a teacher - A measure of rationality regarding pedagogical processes. Procedia - Social and Behavioral Sciences, 89, 751-755. https://doi. org/10.1016/j.sbspro.2013.08.927

Walder, A. M. (2014). The concept of pedagogical innovation in higher education. Education Journal, 3(3), 195-202. https://doi. org/10.11648/j.edu.20140303.22

Zarudnaya, M., Fominykh, N., Enygin, D., Kudysheva, A., Epifanov, D., \& Eferova, A. (2018). Methodological approaches to university instructors professional foreign languages competence development. The Journal of Social Sciences Research, 5, 375-381. https://doi.org/10.32861/jssr.spi5.375.381 
Aubakirova et al. (2021). Consideration of the basic competencies of a preschool teacher in curriculum modernization, International Journal of Cognitive Research in Science, Engineering and Education (IJCRSEE), 9(1), 91-103. 